\title{
Pengembangan Modul Intervensi untuk Meningkatkan Resiliensi pada Individu yang Mengalami Perubahan Fisik Menjadi Penyandang Disabilitas
}

\author{
Wiwin Hendriani \\ Departemen Psikologi Pendidikan dan Perkembangan Fak. Psikologi Universitas Airlangga, Surabaya
}

\begin{abstract}
This study aimed to follow up the previous research findings in developing an intervention module to be used as a guide to improve the resilience of individuals who experience physical changes of being an disabled individual. Researcher compiled and elaborated the initial implementation plan recommended by previous research to be more systematic and operational. The method used was action research stage, although the process was only conducted until in the third step. Participants consisted of eight individuals who experienced physical changes to be individuals with disability. Besides the participants, four psychologists were involved as module reviewers. A module package of interventions to improve resilience resulted from this research consisted of two main steps; (1) strengthening protective factors; and (2) developing coping and adaptation strategies. Those steps then divided into 5 sub-modules that were designed to facilitate its implementation; (1) strengthening family support to person with disabilities; (2) initial assitance of person with disabilities; (3) further intervention 1 (strengthening internal protective factors); (4) further intervention 2 (developing coping strategies); and (5) further intervention 3 (developing positive adaptation).
\end{abstract}

Key words: disability, intervention module, resilience

\begin{abstract}
Abstrak.
Penelitian ini bertujuan untuk menindaklanjuti temuan sebelumnya dengan mengembangkan modul intervensi secara terperinci, yang selanjutnya dapat digunakan sebagai panduan dalam membantu meningkatkan resiliensi individu yang mengalami perubahan kondisi fisik menjadi penyandang disabilitas. Penulis menyusun serta merinci rancangan implementasi awal yang direkomendasikan oleh penelitian sebelumnya kedalam langkah-langkah yang lebih sistematis dan operasional hingga memperoleh hasil akhir berupa modul. Metode yang digunakan berbasis tahapan riset aksi, meskipun proses yang dilakukan hanya sampai pada langkah ketiga, yaitu perumusan solusi dari persoalan yang diangkat. Partisipan terdiri dari delapan individu yang mengalami perubahan kondisi menjadi penyandang disabilitas. Selain partisipan, empat orang psikolog juga dilibatkan dalam penelitian ini sebagai penelaah modul. Hasil penelitian ini berupa sebuah paket modul intervensi untuk peningkatan resiliensi melalui penguatan faktor protektif serta pengembangan strategi koping dan adaptasi pada individu yang mengalami perubahan kondisi fisik menjadi penyandang disabilitas. Paket modul tersebut terdiri dari 5 sub-modul yang telah disusun sedemikian rupa untuk memudahkan pelaksanaannya, terdiri dari modul: (1) memperkuat dukungan keluarga terhadap penyandang disabilitas; (2) pendampingan awal penyandang disabilitas; (3) intervensi lanjut 1 (penguatan faktor protektif internal); (4) intervensi lanjut 2 (pengembangan strategi koping); dan (5) intervensi lanjut 3 (langkah adaptasi positif).
\end{abstract}

Kata Kunci: modul intervensi, penyandang disabilitas, resiliensi

Korespondensi: Departemen Psikologi Pendidikan dan Perkembangan Fakultas Psikologi Universitas Airlangga Jln. Airlangga 4-6 Surabaya, telp. (031) 5032770, e-mail: wiwin.hendriani@psikologi.unair.ac.id 


\section{PENDAHULUAN}

Disabilitas yang terjadi secara tiba-tiba, tidak sejak lahir atau saat fase awal masa perkembangan akan memberikan dampak psikologis yang cukup besar bagi individu. Disabilitas yang terjadi secara mendadak dapat mengancam identitas, sehingga tidak sedikit yang kemudian merasakan kesulitan untuk menjalani hidup seperti waktu-waktu sebelumnya (Tarsidi, 2008). Tekanan psikologis semacam ini terjadi tidak lain karena individu yang mengalaminya dihadapkan pada serangkaian perubahan yang signifikan dalam hidup, baik dalam hubungan keluarga, relasi sosial, maupun dalam menjalankan berbagai macam peran di masyarakat. Selain itu, beban pun bertambah manakala individu menyadari bahwa respon lingkungan masih kurang menerima keberadaan penyandang disabilitas.

Mengingat fakta telah menunjukkan banyaknya individu yang tidak mampu mengatasi beratnya problem psikologis dalam perubahan kondisi menjadi penyandang disabilitas (Tarsidi, 2008; Inoy, 2012; Utomo, 2012; Yudistia, 2011; Ferrasta, 2010), maka membantu individu yang berada pada situasi ini agar mampu bangkit dari keterpurukan menjadi hal yang sangat penting untuk diupayakan. Intervensi untuk mengoptimalkan resiliensi menjadi sangat dibutuhkan dan tidak kalah penting dari berbagai program rehabilitasi disabilitas yang lain. Hal ini karena pemulihan psikologis juga akan berperan besar terhadap kondisi kesehatan individu selanjutnya. Resiliensi akan memungkinkan individu mampu memunculkan respon perilaku adaptif terhadap kondisi yang baru dan menjalani hidup sebagai penyandang disabilitas dengan tetap optimis dan produktif.

Kebutuhan intervensi untuk meningkatkan resiliensi ini semakin mendesak karena angka kejadian disabilitas yang cenderung meningkat dari tahun ke tahun. Data prevalensi penyandang disabilitas telah dirilis setidaknya oleh beberapa sumber, yakni WHO dan Kemenkes. WHO melakukan quick survey pada tahun 1979 dan menyimpulkan bahwa prevalensi disabilitas di Indonesia mencapai $3.11 \%$, dan diasumsikan masih akan terus bertambah pada tahun-tahun berikutnya. WHO memperkirakan bahwa pada tahun 2004, populasi penyandang disabilitas mencapai $10 \%$ dari total seluruh penduduk Indonesia ("Penyandang Cacat Juga Anak Bangsa," 2008). Sementara menurut Survei Kesehatan Rumah Tangga Departemen Kesehatan tahun 2001, prevalensi disabilitas di Indonesia sudah mencapai 3.9\% dari jumlah penduduk (Kasim, 2007).

Akan tetapi yang menjadi persoalan kemudian, ketersediaan panduan untuk melaksanakan intervensi peningkatan resiliensi tersebut rupanya juga masih belum sejalan dengan kebutuhannya. Hingga saat ini belum terdapat modul yang secara khusus dapat digunakan untuk memandu proses intervensi peningkatan resiliensi pada individu yang mengalami perubahan kondisi fisik menjadi penyandang disabilitas. Namun demikian telah terdapat penelitian yang secara rinci menguraikan proses seseorang mencapai resiliensi dalam perubahan kondisi fisiknya menjadi penyandang disabilitas. Penelitian yang dilakukan oleh Hendriani (2013) tersebut telah melengkapi hasilnya dengan saran rekomendasi yang dapat digunakan sebagai petunjuk dalam penyusunan modul intervensi peningkatan resiliensi pada individu dalam konteks persoalan yang sama.

Oleh karena itu, penelitian ini ditujukan untuk menindaklanjuti penelitian Hendriani (2013) dalam mengembangkan modul intervensi secara terperinci, yang selanjutnya dapat digunakan sebagai panduan dalam membantu meningkatkan resiliensi individu yang mengalami perubahan kondisi fisik menjadi penyandang disabilitas. 


\section{RESILIENSI DAN PROSES PENCAPAIANNYA}

Lazarus (1993 dalam Tugade \& Fredricson, 2004) mendefinisikan resiliensi psikologis sebagai koping efektif dan adaptasi positif terhadap kesulitan dan tekanan. Sementara menurut Richardson (2002), resiliensi adalah proses koping terhadap stresor, kesulitan, perubahan, maupun tantangan yang dipengaruhi oleh faktor protektif. Resiliensi psikologis ini akan mencerminkan bagaimana kekuatan dan ketangguhan yang ada dalam diri seseorang. Resiliensi psikologis ditandai dengan kemampuan untuk bangkit dari pengalaman emosional yang negatif. Seorang yang resilien akan berusaha untuk menghadapi dan kemudian bangkit dari berbagai kondisi stres dengan kemampuan yang dimiliki (Block \& Kremen, 1996 dalam Tugade \& Fredricson, 2004).

Resiliensi bukan trait yang bersifat statis (Cicchetti \& Toth, 1998 dalam Kalil, 2003), yang dimiliki oleh seseorang sejak lahir, atau secara otomatis bertahan dalam diri seseorang setelah sekali ia berhasil mencapainya (Meichenbaum, 2008). Resiliensi merupakan proses dinamis yang mencakup adaptasi positif dalam konteks situasi yang sulit, mengandung bahaya maupun hambatan yang signifikan, yang dapat berubah sejalan dengan waktu dan lingkungan yang berbeda (Luthar dkk., 200o; Cicchetti \& Toth, 1998, dalam Kalil, 2003). Resiliensi adalah proses interaktif kompleks yang melibatkan berbagai karakteristik individu, keluarga, maupun lingkungan masyarakat yang lebih luas (Meichenbaum, 2008).

Berdasarkan penjelasan teoritik tersebut, disimpulkan bahwa resiliensi merupakan sebuah proses dinamis yang melibatkan peran berbagai faktor individual maupun sosial, yang mencerminkan kekuatan dan ketangguhan seseorang untuk bangkit dari pengalaman emosional negatif, saat menghadapi situasi sulit yang menekan atau mengandung hambatan yang signifikan. Penelitian Hendriani (2013) memperjelas simpulan tersebut dengan merumuskan proses dinamis yang dimaksud dengan menggunakan strategi grounded theory. Proses resiliensi dalam penelitian Hendriani (2013) diteliti dalam konteks perubahan kondisi menjadi penyandang disabilitas.

Kerangka teoretis yang telah dirumuskan oleh Hendriani (2013) menjelaskan bahwa proses resiliensi terhadap perubahan kondisi fisik menjadi penyandang disabilitas berlangsung dalam empat fase yaitu fase stres, fase rekonstruksi diri, fase penguatan, dan fase resilien. Sebagai fase kunci dalam proses resiliensi, fase rekonstruksi diri ditandai oleh adanya koping dan adaptasi positif yang mampu dilakukan oleh individu. Koping dan adaptasi ini ditentukan oleh sejumlah faktor protektif, baik internal maupun eksternal yang berperan memperkuat kondisi psikologis individu dalam menghadapi stresor maupun mengurangi efek negatif dari faktor risiko. Mengingat dalam perjalanan hidup individu berbagai persoalan terkait kondisi fisiknya sebagai penyandang disabilitas datang silih berganti dan kadang terus berulang, maka fase-fase dalam proses resiliensi tersebut berlangsung secara sirkuler.

Pada fase pertama, yaitu stres, berlangsung selama kurang lebih satu tahun setelah terjadinya disabilitas, meskipun secara spesifik lama waktu tersebut berbeda-beda antar individu. Fase ini ditandai dengan meningkatnya emosi negatif sebagai kelanjutan dari tekanan yang sudah mulai tampak pada fase pertama. Tekanan pada individu disebabkan oleh tiga kelompok stresor, yaitu: karakteristik disabilitas, kebutuhan hidup, dan sikap negatif masyarakat terhadap penyandang disabilitas. Stres individu diikuti oleh sejumlah respon, baik yang bersifat fisiologis maupun psikologis.

Kemudian fase kedua merupakan saat individu bangkit menyesuaikan diri dengan kondisi baru dan merekonstruksi kembali 


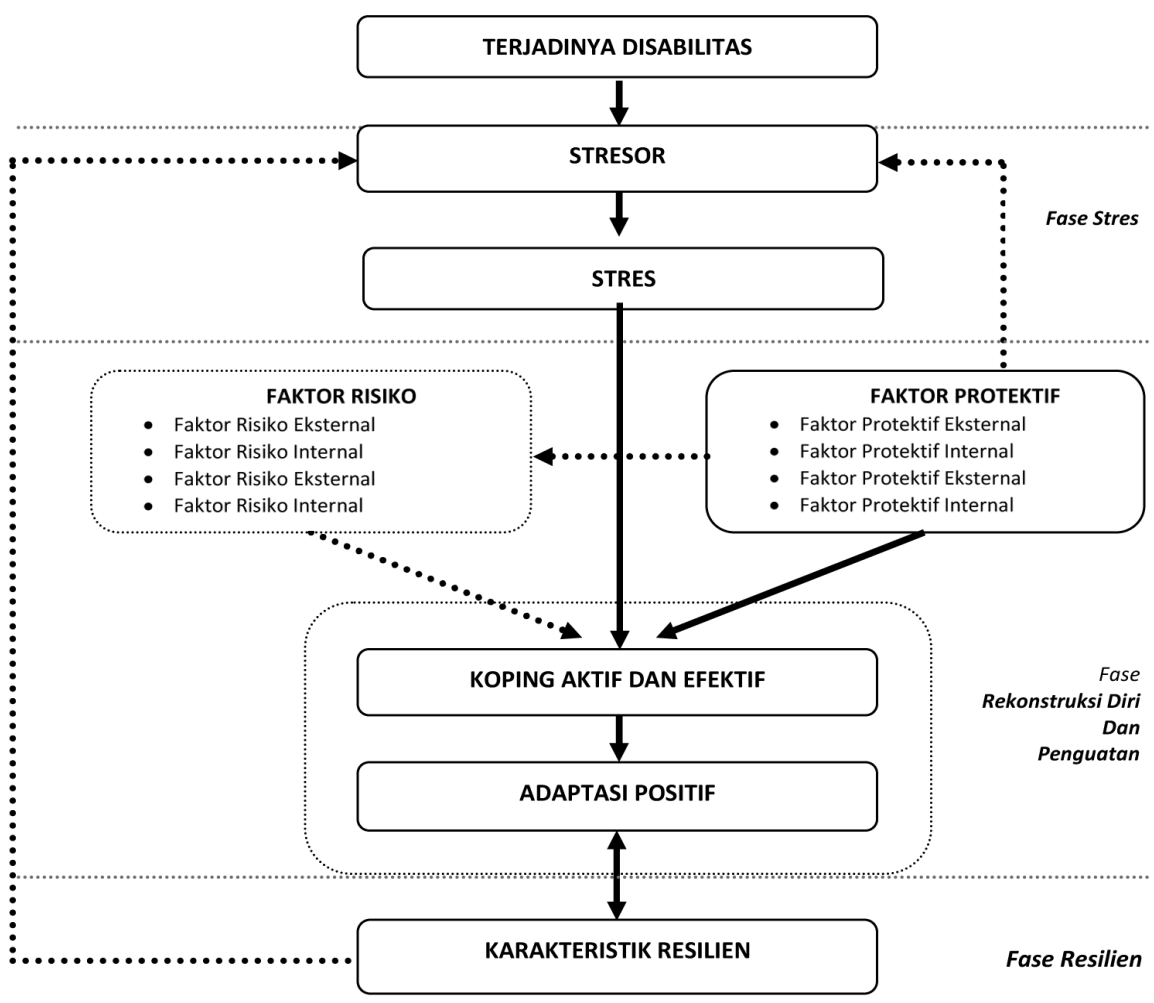

Gambar 1. Proses Resiliensi Individu dalam Perubahan Kondisi Fisik Menjadi Penyandang Disabilitas (Hendriani, 2013)

berbagai pemikiran negatif terhadap situasi yang dihadapi menjadi pemahaman baru yang lebih positif. Individu bergerak meninggalkan situasi yang sebelumnya banyak didominasi oleh emosi negatif, menuju kondisi psikologis yang lebih tenang dan bersemangat untuk melanjutkan hidup. Faktor yang berperan pada fase ini adalah faktor risiko dan faktor protektif. Keduanya berpengaruh terhadap strategi dalam menghadapi tekanan yang dirasakan. Antara faktor risiko dengan faktor protektif dalam penelitian ini merupakan konstruk-konstruk yang sama namun berada pada titik ekstrem yang berlawanan. Faktor risiko berada pada ekstrem negatif, sedangkan faktor protektif berada pada ekstrem positif.

Faktor risiko dan faktor protektif tersebut mencakup; dukungan keluarga, kesadaran akan dukungan sosial, religiusitas, intervensi psikologis, keberadaan sumber inspirasi, kemauan belajar, kesadaran akan tanggung jawab, dan fasilitas umum yang tersedia untuk penyandang disabilitas. Adapun strategi dari individu yang menghadapi tekanan terkait perubahan kondisinya menjadi penyandang disabilitas terdiri dari dua proses, yaitu koping dan adaptasi.

Koping individu mencakup langkahlangkah: Memberikan makna positif terhadap kejadian yang tidak menyenangkan, memotivasi dan meyakinkan diri untuk mampu menjalani hidup dan tetap beraktivitas dengan baik, mencari alasan penguat untuk lebih banyak bersyukur, dan bersikap realistis. Sementara proses adaptasi yang teridentifikasi dalam penelitian ini terdiri dari langkah; mengubah persepsi negatif menjadi sesuatu yang lebih positif, mencari cara baru untuk 
melakukan aktivitas, mengembangkan komunitas sosial terutama dengan sesama penyandang disabilitas, serta meningkatkan penghargaan terhadap diri sendiri.

Kemudian fase ketiga, penguatan, ditandai oleh menguatnya kepercayaan diri individu dengan kondisi dan identitas yang baru sebagai seorang penyandang disabilitas. Individu menunjukkan lebih banyak emosi positif, semakin meminimalkan respon emosi negatif, serta memfokuskan waktu untuk melakukan aktivitas yang produktif. Strategi koping dan adaptasi yang sudah mulai dilakukan pada fase penyesuaian semakin diperkuat selama fase ini.

Fase terakhir atau keempaat ditandai oleh kondisi psikologis individu yang stabil dan karakteristik perilaku resilien, antara lain; mampu sepenuhnya menerima diri sebagai seorang penyandang disabilitas, semakin baik dalam mengelola emosi, munculnya kepekaan sosial, adanya berbagai respon positif terhadap situasi negatif berikutnya, serta semangat dan usaha keras untuk tetap produktif berkarya.

\section{METODE}

Penelitian ini menerapkan tahapan riset aksi (action research) dalam merumuskan suatu model intervensi untuk membantu meningkatkan koping efektif dan adaptasi positif individu terhadap perubahan fisik mereka menjadi penyandang disabilitas. Greenwood dan Levin (2007) menjelaskan bahwa riset aksi memiliki tiga elemen utama. Elemen pertama, yakni aksi, menyatakan suatu tindakan yang ditujukan untuk mengubah kelompok atau organisasi tertentu menjadi ke dalam kondisi yang lebih membebaskan. Aksi pembebasan ini bisa dimaknai beragam; makna yang sejalan dengan penelitian ini adalah pembebasan melalui peningkatan kesadaran diri penyandang disabilitas, yang mana dengan mencapai resiliensi, para penyandang disabilitas diharapkan dapat memandang diri mereka lebih lebih positif, dan tentunya kontributif, bukan sebagai kelompok yang disisihkan dalam masyarakat. Elemen kedua adalah elemen riset; usaha mencapai kondisi yang lebih membebaskan dicapai melalui serangkaian proses penelitian. Elemen ketiga adalah partisipasi. Melibatkan partisipan dalam penelitian sebagai rekan peneliti, bukan semata-mata partisipan merupakan ciri khas riset aksi. Peneliti bekerja bersama-sama dengan partisipan untuk mendefinisikan masalah yang terjadi, merumuskan solusi, mengimplementasikan solusi tersebut, serta merefleksikan kembali aksi yang telah dilakukan.

Secara konseptual, model riset aksi digambarkan Greenwood dan Levin (2007) sebagai berikut:

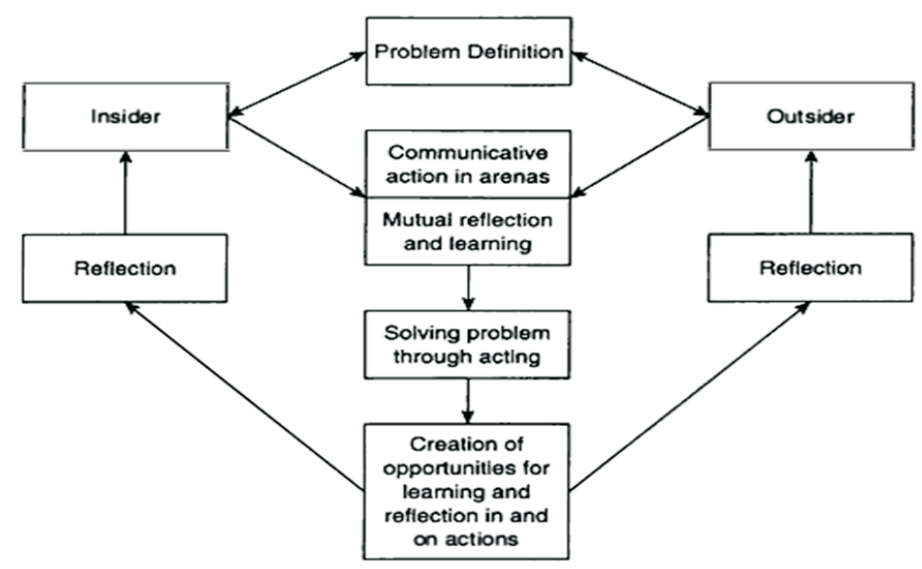

Gambar 2. Model Riset Aksi Kogeneratif (Greenwood \& Levin, 2007) 
Proses riset aksi sebagaimana dijelaskan oleh Greenwood dan Levin (2007) dalam bagan di atas memiliki beberapa tahapan: (1) Refleksi menjadi tahap awal di mana peneliti mengamati fenomena sosial dalam masyarakat; (2) Tahap pendefinisian masalah. Ciri khas riset aksi di operasional hingga memperoleh luaran berupa modul. Modul ini kemudian diulas oleh empat orang psikolog, yakni psikolog klinis, psikolog pendidikan, psikolog perkembangan, dan psikolog sosial untuk memperoleh masukan dari berbagai sudut pandang.

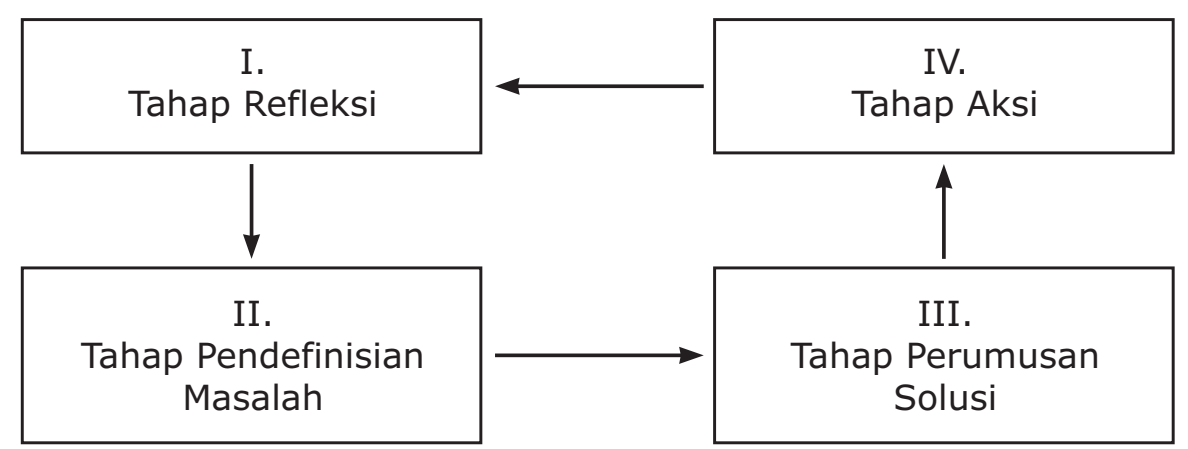

Gambar 3. Model Riset Aksi, Adaptasi dari Greenwood dan Levin (2007)

sini adalah peneliti mengajak kelompok partisipan untuk mendefinisikan masalah yang dihadapi bersama-sama dengan sedetil mungkin melalui penggalian data dalam kelompok tersebut; (3) Tahap ketiga adalah merumuskan solusi bersama kelompok partisipan. Kembali, ciri khas riset aksi adalah solusi yang dirumuskan bukanlah solusi yang didominasi oleh peneliti, namun merupakan hasil belajar bersama dengan kelompok partisipan; dan (4) Tahap keempat adalah pengujian solusi tersebut melalui implementasi atau aksi, yang dilanjutkan dengan melakukan evaluasi dari solusi yang telah dicoba untuk diterapkan.

Atas dasar proses yang sedemikian panjang, penelitian ini pada akhirnya hanya mampu mencakup tiga tahapan riset aksi yang telah dijelaskan Greenwood dan Levin (2007) terlebih dahulu. Tahap pertama dan kedua dilaksanakan dengan melibatkan 8 orang partisipan penyandang disabilitas. Sementara pada tahap ketiga, peneliti menyusun serta memperinci rancangan implementasi awal model intervensi yang dimaksud ke dalam langkah-langkah yang lebih sistematis dan

\section{HASIL PENELITIAN}

Beberapa catatan penting yang mendasari rumusan awal proses intervensi yang kemudian dikembangkan menjadi modul dalam penelitian ini adalah pertama, temuan tentang faktor protektif, strategi koping dan adaptasi merupakan dasar dari intervensi yang dapat diberikan untuk membantu pencapaian resiliensi. Kedua, tahapan intervensi perlu disusun dengan mengacu pada fase-fase dalam proses resiliensi, khususnya fase kedua sampai dengan keempat. Ketiga, intervensi yang ditujukan untuk meredakan tekanan emsosi pasca perubahan kondisi menjadi penyandang disabilitas perlu untuk dilakukan terlebih dahulu sebelum intervensi lain. Hal ini mengingat semakin awal tekanan dapat diredakan, semakin dini emosi-emosi negatif dapat dinetralisir, maka semakin cepat pula individu bangkit dan melakukan penyesuaian terhadap kondisinya yang baru. Dalam intervensi awal ini, akan lebih baik apabila kepada individu dapat dilatihkan teknik-teknik tertentu untuk meredakan emosi yang dapat diterapkan secara mandiri di luar waktu intervensi. 
Pengembangan Modul Intervensi untuk Meningkatkan Resiliensi pada Individu yang Mengalami Perubahan Fisik ...

Keempat, berdasarkan pengalaman partisipan penelitian, pendampingan psikologis yang hanya dilakukan dengan konseling bersama psikolog atau sukarelawan yang tidak memiliki pengalaman disabilitas akan rentan untuk mengalami penolakan. Individu akan cenderung resisten terhadap masukan yang diberikan, menganggap bahwa psikolog atau sukarelawan hanya berbicara teoretis, dan mudah memberikan nasihat karena tidak mengalami sendiri kejadian yang dirasakan oleh individu. Hal ini akan berbeda jika proses pendampingan dapat dilakukan dengan melibatkan penyandang disabilitas lain sebagai pendamping atau sosok yang diharapkan mampu memberikan inspirasi pada individu yang sedang berusaha menyesuaikan diri sebagai penyandang disabilitas yang baru. Kelima, dalam proses intervensi, aktivitas tertentu dapat disusun untuk sekaligus memfasilitasi pengembangan beberapa faktor protektif yang sejalan, sehingga proses menjadi lebih efisien.

Lebih lanjut, rumusan awal proses intervensi untuk meningkatkan resiliensi difokuskan pada dua tujuan, yaitu memperkuat faktor protektif dan memberikan gambaran tentang strategi koping yang efektif dan adaptasi positif yang dapat dilakukan untuk mengatasi tekanan dalam mencapai resiliensi. Sasaran implementasi adalah individu penyandang disabilitas dan keluarga sebagai lingkungan terdekat. Pemetaan pokok aktivitas intervensi kemudian dituangkan pada tabel 1 .

Tabel 1. Pemetaan Pokok-Pokok Aktivitas dalam Model Intervensi Peningkatan Resiliensi

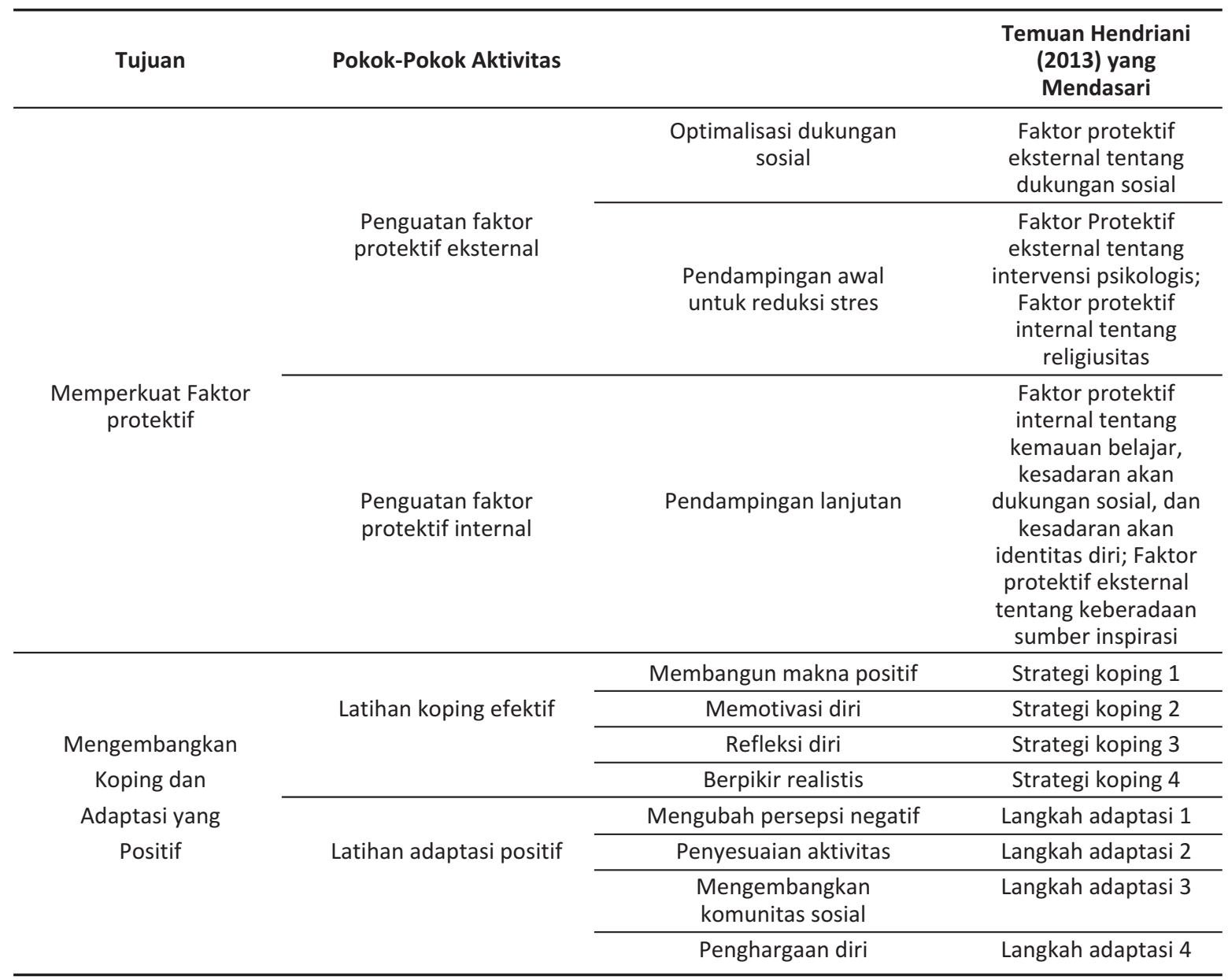


Sejalan dengan proses resiliensi yang telah dirumuskan dalam penelitian Hendriani (2013), tahap intervensi untuk memperkuat faktor protektif dirancang untuk dilaksanakan lebih dahulu, sebelum tahap pengembangan koping dan adaptasi. Penguatan faktor protektif terbagi dalam dua langkah, yaitu penguatan faktor protektif eksternal dan penguatan faktor protektif internal.

Penguatan faktor protektif eksternal diberikan lebih awal terkait dengan penyiapan keluarga sebagai lingkungan pendukung utama dalam proses resiliensi individu, serta upaya membantu menurunkan stres yang harus segera dilakukan sebelum beban yang dirasakan individu semakin bertambah berat. Dua aktivitas dalam penguatan faktor protektif eksternal ini meliputi: (1) optimalisasi dukungan orangtua melalui berbagai aktivitas yang dapat dirancang lebih lanjut dalam modul intervensi yang lebih spesifik; dan (2) pendampingan awal untuk membantu individu menurunkan tekanan yang dirasakan (reduksi stres), dengan memperkuat aspek religiusitas serta menerapkan beragam teknik terapi (relaksasi, meditasi dan sebagainya). Kedua aktivitas tersebut disarankan untuk dapat dilaksanakan secara simultan, dalam waktu yang bersamaan.

Penguatan faktor protektif eksternal akan diikuti oleh penguatan faktor protektif internal yang berisi langkah-langkah pendampingan lanjut. Pendampingan lanjut ditujukan untuk meningkatkan kemauan belajar individu, kesadaran akan dukungan sosial, dan kesadarannya terhadap tanggung jawab yang masih dimiliki. Pada tahap ini penting untuk dapat menghadirkan sosok penyandang disabilitas resilien, yang mampu memberikan motivasi dan inspirasi bagi individu untuk tidak menyerah pada keadaan.

Tahap kedua setelah penguatan faktor protektif eksternal dan internal adalah pengembangan koping dan adaptasi. Pada tahap ini individu diberikan gambaran sekaligus difasilitasi untuk berlatih tentang beberapa strategi koping yang efektif dan adaptasi yang positif terhadap situasi sulit yang setiap saat mungkin akan ditemui sebagai seorang penyandang disabilitas yang baru.

Tabel 2. Garis Besar Intervensi

\begin{tabular}{|c|c|c|c|c|}
\hline Tujuan Khusus & Tahap Intervensi & Aktivitas & Sasaran & Waktu \\
\hline \multirow[t]{2}{*}{$\begin{array}{l}\text { 1. Memperkuat Faktor } \\
\text { Protektif Eksternal }\end{array}$} & $\begin{array}{l}\text { Memperkuat Dukungan } \\
\text { Keluarga }\end{array}$ & Training & $\begin{array}{l}\text { Keluarga Penyandang } \\
\text { Disabilitas }\end{array}$ & \\
\hline & Pendampingan Awal & $\begin{array}{l}\text { Konseling \& } \\
\text { latihan } \\
\text { relaksasi }\end{array}$ & $\begin{array}{l}\text { Individu Penyandang } \\
\text { Disabilitas }\end{array}$ & 2 mggu: 4 sesi \\
\hline $\begin{array}{l}\text { 2. Memperkuat Faktor } \\
\text { Protektif Internal }\end{array}$ & $\begin{array}{l}\text { Intervensi Lanjut I : } 3 \\
\text { Faktor Protektif } \\
\text { Internal }\end{array}$ & $\begin{array}{l}\text { Training \& } \\
\text { konseling }\end{array}$ & $\begin{array}{l}\text { Individu Penyandang } \\
\text { Disabilitas }\end{array}$ & $\begin{array}{l}1 \text { hari training } \\
\text { (4 sesi) } \\
2 \text { kali konseling }\end{array}$ \\
\hline $\begin{array}{l}\text { 3. Mengembangkan } \\
\text { Strategi Koping }\end{array}$ & $\begin{array}{l}\text { Intervensi Lanjut II : } 3 \\
\text { Strategi Koping } \\
2 \text { kali konseling }\end{array}$ & $\begin{array}{l}\text { Training \& } \\
\text { konseling }\end{array}$ & $\begin{array}{l}\text { Individu Penyandang } \\
\text { Disabilitas }\end{array}$ & $\begin{array}{l}1 \text { hari training } \\
\text { (4 sesi) }\end{array}$ \\
\hline $\begin{array}{l}\text { 4. Mengembangkan } \\
\text { Adaptasi Positif }\end{array}$ & $\begin{array}{l}\text { Intervensi Lanjut III: } 3 \\
\text { Langkah Adaptasi } \\
\text { Positif }\end{array}$ & $\begin{array}{l}\text { Training \& } \\
\text { Konseling }\end{array}$ & $\begin{array}{l}\text { Individu Penyandang } \\
\text { Disabilitas }\end{array}$ & $\begin{array}{l}1 \text { hari training } \\
\text { (4 sesi) } \\
2 \text { kali konseling }\end{array}$ \\
\hline
\end{tabular}


Pengembangan Modul Intervensi untuk Meningkatkan Resiliensi pada Individu yang Mengalami Perubahan Fisik ...

Pada dasarnya setiap individu dapat saja mengembangkan strategi koping masingmasing yang belum tentu sama dengan temuan dalam penelitian ini. Namun demikian, langkah untuk memberikan gambaran tentang bagaimana strategi koping yang efektif dan adaptasi positif tersebut tetap penting untuk dilakukan. Tujuannya tidak lain untuk mempercepat individu lepas dari tekanan dan menemukan jalan untuk kembali berdaya dalam hidupnya.
Dalam pelaksanaannya, keempat tujuan khusus intervensi tersebut dipecah menjadi 5 tahap intervensi yang masing-masing diuraikan panduan pelaksanaannya dalam detil modul yang berbeda (tabel 3 ).

\section{SIMPULAN}

Penelitian ini telah menghasilkan sebuah paket modul intervensi untuk peningkatan resiliensi melalui penguatan faktor protektif

Tabel 3. Sistematika Modul Intervensi

\begin{tabular}{|c|c|c|c|}
\hline Intervensi & Sesi & Materi & Panduan \\
\hline $\begin{array}{l}\text { Memperkuat Dukungan } \\
\text { Keluarga terhadap } \\
\text { Penyandang Disabilitas }\end{array}$ & $\begin{array}{l}1 \\
2 \\
3 \\
4\end{array}$ & $\begin{array}{l}\text { Memahami Resiliensi Individu } \\
\text { Memahami Pentingnya Dukungan Keluarga } \\
\text { Mengoptimalkan Dukungan Keluarga } \\
\text { Penguatan untuk Mengoptimalkan } \\
\text { Dukungan Keluarga }\end{array}$ & Modul 1 \\
\hline $\begin{array}{l}\text { Pendampingan Awal } \\
\text { Penyandang Disabilitas }\end{array}$ & $\begin{array}{l}1 \\
2 \\
3 \\
4\end{array}$ & $\begin{array}{l}\text { Konseling dan Latihan Relaksasi } 1 \\
\text { Konseling dan Latihan Relaksasi } 2 \\
\text { Konseling dan Latihan Relaksasi } 3 \\
\text { Konseling dan Latihan Relaksasi } 4\end{array}$ & Modul 2 \\
\hline $\begin{array}{l}\text { Intervensi Lanjut I : } 3 \\
\text { Faktor Protektif Internal }\end{array}$ & $\begin{array}{l}1 \\
2 \\
3\end{array}$ & $\begin{array}{l}\text { Membangun Kesadaran Terhadap } \\
\text { Dukungan Sosial } \\
\text { Memperkuat Kesadaran Terhadap Identitas Diri } \\
\text { Menumbuhkan Kemauan Belajar }\end{array}$ & Modul 3 \\
\hline $\begin{array}{l}\text { Intervensi Lanjut II : } 3 \\
\text { Strategi Koping }\end{array}$ & $\begin{array}{l}1 \\
2 \\
3\end{array}$ & $\begin{array}{l}\text { Berpikir Reflektif dan Objektif } \\
\text { Membangun Makna Positif } \\
\text { Memotivasi Diri }\end{array}$ & Modul 4 \\
\hline $\begin{array}{l}\text { Intervensi Lanjut III : } 3 \\
\text { Langkah Adaptasi Positif }\end{array}$ & $\begin{array}{l}1 \\
2 \\
3\end{array}$ & $\begin{array}{l}\text { Penyesuaian dalam Aktivitas Sehari-hari } \\
\text { Apresiasi Diri } \\
\text { Mengembangkan Relasi Sosial }\end{array}$ & Modul 5 \\
\hline
\end{tabular}

Secara keseluruhan, paket intervensi yang tertuang dalam modul peningkatan resiliensi melalui penguatan faktor protektif dan pengembangan strategi koping pada individu yang alami perubahan fisik menjadi penyandang disabilitas memiliki 4 cakupan tujuan khusus (tabel 2), yaitu; (1) memperkuat faktor protektif eksternal; (2) memperkuat faktor protektif internal; (3) mengembangkan strategi koping, dan (4) mengembangkan adaptasi positif. dan pengembangan strategi koping pada individu yang mengalami perubahan kondisi fisik menjadi penyandang disabilitas. Paket modul tersebut terdiri dari 5 sub-modul yang telah disusun secara terperinci untuk memudahkan pelaksanaannya.

Dari keseluruhan 4 tahap yang seharusnya terlaksana sebagai sebuah riset aksi, penelitian ini hanya dapat dilaksanakan sampai pada tahap ketiga dengan luaran berupa modul intervensi seperti yang telah dijelaskan. Hal ini menjadi 
kelemahan pertama dari penelitian karena belum adanya umpan balik dari para penyandang disabilitas setelah kelima modul intervensidisusun.

Kelemahan kedua dalam penelitian ini adalah penggunaan istilah intervensi yang secara konseptual bersilang arah dengan prinsip utama riset aksi. Istilah intervensi meng- indikasikan bahwa seorang yang merancang dan memberikan intervensi memiliki posisi epistemologis yang lebih tinggi ketimbang partisipan, sedangkan dalam riset aksi, posisi peneliti dan partisipan adalah sejajar, lebihlebih mereka bekerja sama untuk menyelesaikan masalah yang sedang dihadapi kelompok partisipan.

\section{PUSTAKA ACUAN}

Anonim. (2008). Penyandang Cacat Juga Anak Bangsa. Harian Suara Pembaruan Online, 23 Juli 2008. Diunduh dari: http://www.suarapembaruan.com tanggal 8 Oktober 2010.

Ferrasta, T. (2010). That's All. Jakarta: Cicero Publishing.

Greenwood, D. J. dan Levin, M. (2007) Introduction to action research: Social research for social change, $2^{\text {nd }}$ eds. California:Sage Publication.

Hendriani, W. (2013). Proses Resiliensi Individu dalam Perubahan Kondisi Fisik Menjadi Penyandang Disabilitas. (Disertasi tidak dipubli-kasikan). Fakultas Kesehatan Masyarakat Universitas Airlangga, Surabaya.

Inoy, R. (2012). GBS Tidak Menghalangi Langkahku: Kisah Nyata Ogest, Mantan Penyanyi Cilik Pengidap Guillain Barre Syndrome. Jakarta: PT Gramedia Pustaka Utama.

Kalil, A. (2003). Family Resilience and Good Child Outcomes. Wellington: Ministry of Social Development.

Kasim, E.R. (2007). Masalah Penyandang Cacat dan Aspek Budaya. Diakses dari: http://evakasim.multiply.com. tanggal 8 Oktober 2010.

Meichenbaum, D. (2008). Bolstering Resilience: Benefiting from Lesson Learned. Diakses dari: www.melissainstitute.org. bulan Maret 2011.

Rahadi. (2011). Riset untuk Perubahan Sosial. Naskah tidak dipublikasikan, Fakultas Psikologi, Universitas Airlangga.

Richardson, G. E. (2002). The metatheory of resilience and resiliency. Journal of Clinical Psychology, 58 (3), 307-321.

Tarsidi, D. (2008). Model Konseling Rehabilitasi Bagi Individu Tunanetra Dewasa (Dikembangkan Berdasarkan Studi Kasus Terhadap Individu Tunanetra Dewasa yang Berhasil). (Disertasi tidak dipubli-kasikan). Sekolah Pasca Sarjana Universitas Pendidikan Indonesia, Bandung.

Tugade, M.M., Fredricson, B.L., \& Barrett, L.F. (2004). Psychological Resilience and Positive Emotional Granurality: Examining The Benefits of Positive Emotions on Coping and Health. Journal of Personality, 72:26, December 2004.

Utomo, M. (2012). 2 Detik Mengubah Hidup: Ketika Tuhan Berkehendak Saya Harus Berjalan dalam Kelumpuhan. Solo: Metagraf.

VanBreda, A.D. (2001). Resilience Theory: A Literature Review. Pretoria: South African Military Health Service, Military Psychological Institute, Social Work Research and Development.

Yudistia, A. (2011). Perempuan Tunarungu Menembus Batas. Jakarta: Upnormals Publishing. 